\title{
Are adult neurogenesis and glucocorticoid signaling missing links between stress and depression?
}

\author{
Marin M. Jukić ${ }^{1}$, Vesna Pešić ${ }^{2}$ \\ ${ }^{1}$ Section of Pharmacogenetics, Department of Physiology and Pharmacology, \\ Karolinska Institutet, Stockholm, Sweden \\ ${ }^{2}$ University of Belgrade - Faculty of Pharmacy, Department of Physiology, \\ Vojvode Stepe 450, Belgrade, Serbia
}

Address for correspondence: Nanna Svartz vag 2, 17177 Stockholm, Sweden; marin.jukic@ki.se

\begin{abstract}
Summary
Depression contributes substantially to disease burden worldwide; however despite of this, the progress in understanding its pathophysiology has been extremely slow and the discovery of new therapeutic mechanisms is at a near standstill. The molecular targets of current major classes of antidepressants were all reverse engineered from drugs previously discovered by serendipitous clinical observations. Since the existence of adult-born neurons was unequivocally documented, adult neurogenesis became a very promising, but also very hyped target for antidepressant drugs. Introduction of corticotrophin releasing hormone inhibitors aimed to exploit a prospective reduction of glucocorticoid-mediated inhibition of adult neurogenesis with the aim to produce antidepressant effect. Although these drugs failed to demonstrate efficiency in phase three clinical trials, they provided the following valuable lesions for the future: (1) Inter-species differences between animals and humans should be considered very carefully, (2) Animal model phenotypes mimicking depression should be more robust, preferably shown by multiple behavioral paradigms, and (3) variability between different subgroups of depression should be taken into consideration because of the pronounced heterogeneity of the disease.
\end{abstract}

Key words: Depression, Stress, Hippocampus, Adult neurogenesis,

Glucocorticoid signalization 


\section{Adult neurogenesis}

Neurogenesis is the process of generation and differentiation of stem and progenitor cells into mature neurons. The peak of neurogenesis occurs in embryonic stage, when the brain gets populated by the majority of the neurons; this occurs in embryonic days 14 and 15 in mice and between $11^{\text {th }}$ and $14^{\text {th }}$ postcoital week in humans (1). After the initial round of apoptotic selection, these cells continue the maturation, transforming themselves into fully functional and branched neurons. Under assumption that the neuronal development went without difficulties causing neurodevelopmental disorders, these neurons will serve their physiological role in adulthood enabling the correct function of the central nervous system (CNS). Until recently, the general attitude in neuroscience was that no new neurons are formed in the adulthood in humans, despite of the fact that the proof for adult neurogenesis in rodents was present in the field for a long time (2). This changed by the end of the last century, when the nuclei of the hippocampal neurons of the cancer patients treated with bromodeoxyuridin (BRDU) were found positive for this cytostatic (3). This finding demonstrated that these neurons were created after the initiation of BRDU treatment, and represented a clear proof for the existence of adult neurogenesis in humans.

After the existence of adult neurogenesis was ascertained throughout all mammalian species, the field has focused the efforts into revealing of its role. One of the starting points was the restricted spatial locus of the adult neurogenesis; it occurs only in the subependymal layer of the ventricular zone (SVZ) and the subgranular zone of the hippocampal dentate gyrus in rodents, while in humans the presence of newly born neurons is only proved to occur in hippocampus (3) and recently in striatum $(4,5)$. The other starting point was the assumption that the normal function of adult neurogenesis must reflect the normal function of the brain, while the disturbances in its function could lead to the adaptive, or potentially maladaptive, changes in CNS function. However, the difficulties in analyzing the living human brain lead to the standstill in the research of molecular mechanism of adult neurogenesis, causing the shift in research to the animal models.

A single analogy was the driving force to connect the adult neurogenesis and affective disorders. Neurodevelopmental disorders emerge as a result of the impairment of embryonic neurogenesis and they usually manifest very early in life, whereas the affective disorders usually start to be apparent only in the adulthood. Under the assumption that both of these classes of CNS disorders have similarities in their etiology, impairment in adult neurogenesis could lead to the rise of affective disorders in adulthood. The following series of facts were supporting this hypothesis. 


\section{Role of the hippocampus}

Despite intensive research on the function of the hippocampus there is still some controversy about the basic functions of this structure. Based on the series of correlation studies, evidence is emerging of the involvement of the hippocampal formation in a wide range of psychiatric disorders including Alzheimer's disease, schizophrenia, anxiety disorders and depression (6,7). The hippocampus is considered a part of the limbic system and humans and other mammals having two hippocampi, one in each hemisphere. Hippocampal role in the formation of memory is widely known and generally accepted in the field $(8,9)$. However it also seems to be critically important in regulation of emotions as well $(10,11)$ and it furthermore seems important in regulating the stress response (12). The $\mathrm{HC}$ is one of the most connected areas in the brain, receiving its major input from the entorhinal cortex through the perforant pathway. The entorhinal cortex serves as the major connector between the hippocampus and several different cortical areas including the auditory and olfactory cortices, but also the amygdala (6) indicating that the hippocampal function can be sensitive to external, potentially stressful stimuli. Indeed, hippocampal neurons express glucocorticoid receptors (13), while the prolonged exposure to stress paradigms results in glucocorticoid-mediated reduction in hippocampal size, dendritic branching, and adult neurogenesis (12).

\section{Association between major depression and stress}

Major depressive disorder (MDD) is a common, heterogeneous affective disorder with a life-time prevalence of approximately $17 \%(14,15)$, and it represents the most prevalent psychiatric disorder. The association between stress and MDD is a very consistent finding in psychiatry; however, none of the negative environmental factors is sufficient to predict MDD. Therefore, the association between stress and adult neurogenesis, on its own, is not enough to make any conclusion about the role of adult neurogenesis in the etiology of MDD. A series of studies based on animal models gave strength to the hypothesis that the ablation in adult neurogenesis is responsible, at least in part, for MDD. The therapy of MDD consists of drugs of many classes mainly focused on the increase of monoaminergic neurotransmission. All these treatment classes were found to increase adult neurogenesis in animal models (16). In addition to the antidepressants, behaviors proven to participate in healthy ways of coping in stress and to be helpful in MDD treatment, such as an increase in physical activity (17) and enriched environment (18) were also found to increase adult neurogenesis.

Chronic CORT treatment in mice causes changes in mRNA levels of Fkbp5 and $\mathrm{Nr} 3 \mathrm{cl}$, and a decrease in Fkbp5 DNA methylation in the hippocampus (19), as well as the anxious and depressive phenotype $(19,20)$. Similar FKBP5 and NR3C1 gene methylation and expression changes are following stressful events throughout life in 
humans and are correlated with the onset of MDD $(21,22)$. These similarities in the molecular changes in the brain of a mouse and a human is by no means sufficient proof that mice can be depressed; however, they indicate translational potential of the research of molecular stress mediators from mice to humans.

\section{CRF1 inhibitors as candidate drugs for major depression}

Chronic treatment with fluoxetine is proven to be able to ameliorate anxiety/depression CORT-induced changes in various behavioral paradigms in CORT treated mice (23); this fluoxetine effect is proven to be dependent on intact hippocampal neurogenesis $(20,23,24)$. Corticotrophin release factor (CRF) inhibitors were shown to ameliorate anxiety/depression phenotypes independently of neurogenesis in the hippocampus (24) suggesting that the antidepressant effect of the monoaminergic neurotransmission can be mediated by the suppression of the HPA axis. This hypothesis was facilitated by human data, since the cerebrospinal fluid of depressed patients was found to contain elevated levels of the CRF long time ago (25). Hippocampus was found to be involved in the stress feedback loop where glucocorticoid-sensitive hippocampal neurons terminating the adrenocortical stress response (26) and the newborn neurons in the hippocampus could facilitate this pathway. This is one of the mechanisms which counter balances glucocorticoid positive feedback loop on CRF synthesis and secretion, responsible for maintaining the organism responsive to acute stressors under conditions of chronic stress (27). This mechanism would also explain the long incubation period until the onset of the antidepressant action, since the increase in hippocampal neurogenesis would take time to develop mature neurons able to participate in HPA inhibition. Hypothetically, CRF inhibitors would skip this feedback loop and potentially decrease the time needed for monamine-based antidepressants to act making them very good candidate drugs for the new generation antidepressants.

CRF1 receptors, which are predominantly expressed in rodent CNS unlike CRF2 receptor (28), were also shown to mediate the anxiolytic effects in animal models in pharmacological (24) and genetic studies (29). Therefore, selective CRF1 antagonists could block excessive HPA axis signaling caused by the elevated CRF in the spinal fluid of depressed patients and were speculated to be very promising antidepressant candidates.

\section{Negative results of the clinical studies and the aftermath}

Backed up by the corticosteroid receptor hypothesis of the depression (30), pharmaceutical industry started to develop CRF1 blockers a decade ago. Since peptidic compounds were not able to penetrate throughout blood-brain barrier, the focus of the field was on non-peptidic small molecules. The initial results were encouraging in general (31); the escalating doses of R121919 normalized sleep electroencephalography 
and reduced depressive and anxious symptoms in depressed patients in early clinical trials (32). However, R121919 development was discontinued because of elevated liver enzymes, reversible after treatment discontinuation in a parallel trial (33). Since then, many more CRF1 inhibitors entered clinical trials; however, no subsequent compound has successfully completed a definitive Phase III trial due to the lack of efficiency in results in double-blind, placebo-controlled trials for MDD $(34,35)$. These discouraging results lowered the further effort pharmaceutical companies invested in the development of novel compounds blocking CRF1 and it decreased the faith in the results obtained from animal models for mood disorders in general. This event also contributed to the general trend of gradual withdrawal of pharmaceutical companies from the research focused on affective disorders.

\section{Conclusions and future directions}

Keeping in mind the cost of developing novel compounds in pharmaceutical industry, it is crucial to prevent these types of miss-investments if possible. The explanation of the negative results from phase III clinical studies can have various reasons.

The limitation in translational potential of mouse data to humans is maybe the most obvious limitation of preclinical studies involving animal models. Errors in the research including animal models can be divided in two groups. (A) Objective limitations in these studies originate from the differences between two organisms, which are especially emphasized for the higher brain functions. Some behavioural aspects, such as suicidal thoughts, cannot even be ascertained in animals. In addition, it is impossible to be certain if the same biochemical pathways are behind the same behaviours in rodents and humans, and if the adaptive mechanisms causing antidepressant-like response in rodents are in fact equivalent to the antidepressant action in humans. This can sometimes lead to the misinterpretation of the animal results in humans. CRF2 receptors are not present in the rodent brain (28), while in human brain they are (36). If this fact was not neglected, it might have had directed the industry not to base their research exclusively on CRF1 receptor. Assuming that the CRF2 receptor is not relevant for antidepressant effect was derived from the conclusion that it is not relevant for antidepressant-like effect in mice despite of the known differences in the receptor profile in the brain between species. (B) Methodological limitations in the animal behavior research are also numerous. Anxiety, for example, can be measured in rodents by various behavioral essays; it is unknown if they measure the same aspect of anxiety in animals and it is unclear which one, or ones, is the most appropriate to use for testing a specific hypothesis (37). Frequent, but wrong, practice in behavioral research is to base conclusions on positive results derived from only one of these test. Due to the publishing bias, it is not rare that the negative results from some of these paradigms 
remain unpublished, despite of the fact that they could serve as a valuable data in assessment of the success chance of the clinical study.

Next, the limited knowledge about the mood disorders, namely MDD, is interfering with the selection of the relevant groups for the clinical studies. The wrong selection of treatment groups can then imply false negative results for the efficiency in a clinical trial, despite the possible antidepressant efficiency of the drug in the defined subgroup of patients. High MDD prevalence in general population together with the fact that no SNP achieved genome-wide significant association with MDD using the present GWAS sample sizes (38) underlines the fact that MDD is a very heterogeneous disease. Under these conditions, it is possible that CRF1 inhibitors could be very effective treatment of a group selected by closely defined criteria and that this effect is diluted and remained undetected in the randomized group of MDD patients.

Taken together, despite of the insufficient antidepressant efficiency of CRF1 inhibitors in general MDD patient population, they might still be effective in a specific subgroup of MDD patients, namely the subset of patients with the elevated CRF in cerebrospinal fluid. New technical developments and diagnostic tools might eventually lead to a more successful treatment of major depression with CRF1 receptor blockers. The proofs of the involvement of adult neurogenesis in the hippocampus in stress perception and antidepressant effect are abundant. The role of newborn neurons is probably not confined only to the regulation of HPA axis and it might induce antidepressant effect through other pathways.

\section{References}

1. Clancy B., Darlington RB., Finlay BL. Translating developmental time across mammalian species. Neuroscience 2001; 105: 7-17.

2. Altman J. and Das GD. Autoradiographic and histological evidence of postnatal hippocampal neurogenesis in rats. J Comp Neurol 1965; 124: 319-335.

3. Eriksson PS., Perfilieva E., Bjork-Eriksson T., Alborn AM., Nordborg C., Peterson DA., Gage FH. Neurogenesis in the adult human hippocampus. Nat Med 1998; 4: 1313-1317.

4. $\quad$ Ernst A., Alkass K., Bernard S., Salehpour M., Perl S., Tisdale J., Possnert G., Druid H., Frisen J. Neurogenesis in the striatum of the adult human brain. Cell 2014; 156: 1072-1083.

5. Kempermann G. Off the beaten track: new neurons in the adult human striatum. Cell 2014; 156 : 870-871.

6. $\quad$ Small SA., Schobel SA., Buxton RB., Witter MP., Barnes CA. A pathophysiological framework of hippocampal dysfunction in ageing and disease. Nat Rev Neurosci 2011; 12: 585-601.

7. Videbech P. and Ravnkilde B. Hippocampal volume and depression: a meta-analysis of MRI studies. Am J Psychiatry 2004. 161: 1957-1966. 
8. Deng W., Aimone JB., Gage FH. New neurons and new memories: how does adult hippocampal neurogenesis affect learning and memory? Nat Rev Neurosci 2010; 11: 339-350.

9. Lagali PS., Corcoran CP., Picketts DJ. Hippocampus development and function: role of epigenetic factors and implications for cognitive disease. Clin Genet 2010; 78: 321-333.

10. Fanselow MS. and Dong HW. Are the dorsal and ventral hippocampus functionally distinct structures? Neuron 2010; 65: 7-19.

11. Femenia T., Gomez-Galan M., Lindskog M., Magara S. Dysfunctional hippocampal activity affects emotion and cognition in mood disorders. Brain Res 2012; 476: 58-70.

12. McEwen BS. Plasticity of the hippocampus: adaptation to chronic stress and allostatic load. Ann N Y Acad Sci 2001; 933: 265-277.

13. McEwen BS., Weiss JM., Schwartz LS. Selective retention of corticosterone by limbic structures in rat brain. Nature 1968; 220: 911-912.

14. Belmaker RH. and Agam G. Major depressive disorder. N Engl J Med 2008; 358: 55-68.

15. Kessler RC., Berglund P., Demler O., Jin R., Merikangas KR., Walters EE. Lifetime prevalence and age-of-onset distributions of DSM-IV disorders in the National Comorbidity Survey Replication. Arch Gen Psychiatry 2005; 62: 593-602.

16. Malberg JE., Eisch AJ., Nestler EJ., Duman RS. Chronic antidepressant treatment increases neurogenesis in adult rat hippocampus. J Neurosci 2000; 20: 9104-9110.

17. van Praag H., Kempermann G., Gage FH. Running increases cell proliferation and neurogenesis in the adult mouse dentate gyrus. Nat Neurosci 1999; 2: 266-270.

18. Nilsson M., Perfilieva E., Johansson U., Orwar O., Eriksson PS. Enriched environment increases neurogenesis in the adult rat dentate gyrus and improves spatial memory. J Neurobiol 1999; 39 : 569-578.

19. Lee RS., Tamashiro KL., Yang X., Purcell RH., Harvey A., Willour VL., Huo Y., Rongione M., Wand GS., Potash JB. Chronic corticosterone exposure increases expression and decreases deoxyribonucleic acid methylation of Fkbp5 in mice. Endocrinology 2010; 151: 4332-4343.

20. Murray F., Smith DW., Hutson PH. Chronic low dose corticosterone exposure decreased hippocampal cell proliferation, volume and induced anxiety and depression like behaviours in mice. Eur J Pharmacol 2008; 583: 115-127.

21. Klengel T., Mehta D., Anacker C., Rex-Haffner M., Pruessner JC., Pariante CM., Pace TW., Mercer KB., Mayberg HS., Bradley B., Nemeroff CB., Holsboer F., Heim CM., Ressler KJ., Rein T., Binder EB. Allele-specific FKBP5 DNA demethylation mediates gene-childhood trauma interactions. Nat Neurosci 2013; 16: 33-41.

22. van der Knaap LJ., Riese H., Hudziak JJ., Verbiest MM., Verhulst FC., Oldehinkel AJ., van Oort FV. Glucocorticoid receptor gene (NR3C1) methylation following stressful events between birth and adolescence. The TRAILS study. Transl Psychiatry 2014; 4: e381. 
23. David DJ., Samuels BA., Rainer Q., Wang JW., Marsteller D., Mendez I., Drew M., Craig DA., Guiard BP., Guilloux JP., Artymyshyn RP., Gardier AM., Gerald C., Antonijevic IA., Leonardo ED., Hen R. Neurogenesis-dependent and -independent effects of fluoxetine in an animal model of anxiety/depression. Neuron 2009; 62: 479-493.

24. Surget A., Tanti A., Leonardo ED., Laugeray A., Rainer Q., Touma C., Palme R., Griebel G., Ibarguen-Vargas Y., Hen R., Belzung C. Antidepressants recruit new neurons to improve stress response regulation. Mol Psychiatry 2011; 16: 1177-1188.

25. Nemeroff CB., Widerlov E., Bissette G., Walleus H., Karlsson I., Eklund K., Kilts CD., Loosen PT., Vale W. Elevated concentrations of CSF corticotropin-releasing factor-like immunoreactivity in depressed patients. Science 1984; 226: 1342-1344.

26. Sapolsky RM., Krey LC., McEwen BS. Glucocorticoid-sensitive hippocampal neurons are involved in terminating the adrenocortical stress response. Proc Natl Acad Sci U S A 1984; 81: 6174-6177.

27. Makino S., Hashimoto K., Gold PW. Multiple feedback mechanisms activating corticotropinreleasing hormone system in the brain during stress. Pharmacol Biochem Behav 2002; 73: 147158.

28. Chalmers DT., Lovenberg TW., De Souza EB. Localization of novel corticotropin-releasing factor receptor (CRF2) mRNA expression to specific subcortical nuclei in rat brain: comparison with CRF1 receptor mRNA expression. J Neurosci 1995; 15: 6340-6350.

29. Smith GW., Aubry JM., Dellu F., Contarino A., Bilezikjian LM., Gold LH., Chen R., Marchuk Y., Hauser C., Bentley CA., Sawchenko PE., Koob GF., Vale W., Lee KF. Corticotropin releasing factor receptor 1-deficient mice display decreased anxiety, impaired stress response, and aberrant neuroendocrine development. Neuron 1998; 20: 1093-1102.

30. Holsboer F. The corticosteroid receptor hypothesis of depression. Neuropsychopharmacology 2000; 23: 477-501.

31. Holsboer F. and Ising M. Central CRH system in depression and anxiety--evidence from clinical studies with CRH1 receptor antagonists. Eur J Pharmacol 2008; 583: 350-357.

32. Zorrilla EP. and Koob GF. The therapeutic potential of CRF1 antagonists for anxiety. Expert Opin Investig Drugs 2004; 13: 799-828.

33. Zorrilla EP. and Koob GF. Progress in corticotropin-releasing factor-1 antagonist development. Drug Discov Today 2010; 15: 371-383.

34. Binneman B., Feltner D., Kolluri S., Shi Y., Qiu R., Stiger T. A 6-week randomized, placebocontrolled trial of CP-316,311 (a selective CRH1 antagonist) in the treatment of major depression. Am J Psychiatry 2008; 165: 617-620.

35. Paez-Pereda M., Hausch F., Holsboer F. Corticotropin releasing factor receptor antagonists for major depressive disorder. Expert Opin Investig Drugs 2011; 20: 519-535.

36. Hiroi N., Wong ML., Licinio J., Park C., Young M., Gold PW., Chrousos GP., Bornstein SR. Expression of corticotropin releasing hormone receptors type I and type II mRNA in suicide victims and controls. Mol Psychiatry 2001; 6: 540-546. 
37. Ramos A. Animal models of anxiety: do I need multiple tests? Trends Pharmacol Sci 2008; 29: 493-498.

38. Major Depressive Disorder Working Group of the Psychiatric GWAS Consortium: Ripke S, Wray NR, Lewis CM, Hamilton SP, Weissman MM, Breen G, Byrne EM, Blackwood DH, Boomsma DI, Cichon S, Heath AC, Holsboer F, Lucae S, Madden PA, Martin NG, McGuffin P, Muglia P, Noethen MM, Penninx BP, Pergadia ML, Potash JB, Rietschel M, Lin D, Muller-Myhsok B, Shi J, Steinberg S, Grabe HJ, Lichtenstein P, Magnusson P, Perlis RH, Preisig M, Smoller JW, Stefansson K, Uher R, Kutalik Z, Tansey KE, Teumer A, Viktorin A, Barnes MR, Bettecken T, Binder EB, Breuer R, Castro VM, Churchill SE, Coryell WH, Craddock N, Craig IW, Czamara D, De Geus EJ, Degenhardt F, Farmer AE, Fava M, Frank J, Gainer VS, Gallagher PJ, Gordon SD, Goryachev S, Gross M, Guipponi M, Henders AK, Herms S, Hickie IB, Hoefels S, Hoogendijk W, Hottenga JJ, Iosifescu DV, Ising M, Jones I, Jones L, Jung-Ying T, Knowles JA, Kohane IS, Kohli MA, Korszun A, Landen M, Lawson WB, Lewis G, Macintyre D, Maier W, Mattheisen M, McGrath PJ, McIntosh A, McLean A, Middeldorp CM, Middleton L, Montgomery GM, Murphy SN, Nauck M, Nolen WA, Nyholt DR, O'Donovan M, Oskarsson H, Pedersen N, Scheftner WA, Schulz A, Schulze TG, Shyn SI, Sigurdsson E, Slager SL, Smit JH, Stefansson H, Steffens M, Thorgeirsson T, Tozzi F, Treutlein J, Uhr M, van den Oord EJ, Van Grootheest G, Volzke H, Weilburg JB, Willemsen G, Zitman FG, Neale B, Daly M, Levinson DF, Sullivan PF. A megaanalysis of genome-wide association studies for major depressive disorder. Mol Psychiatry 2013; 18: 497-511. 


\title{
Da li su adultna neurogeneza i glukokortikoidna signalizacija spona između stresa i depresije?
}

\author{
Marin M. Jukić ${ }^{1}$, Vesna Pešić ${ }^{2}$ \\ ${ }^{1}$ Section of Pharmacogenetics, Department of Physiology and Pharmacology, \\ Karolinska Institutet, Stockholm, Sweden \\ ${ }^{2}$ Univerzitet u Beogradu - Farmaceutski fakultet, Katedra za fiziologiju, \\ Vojvode Stepe 450, Beograd, Srbija
}

Adresa za korespondenciju: Nanna Svartz vag 2, 17177 Stockholm, Sweden; marin.jukic@ki.se

\begin{abstract}
Kratak sadržaj
Iako depresija značajno doprinosi morbiditetu na globalnom nivou, napredak $\mathrm{u}$ razumevanju patofiziologije ove bolesti je izuzetno spor, pa su posledično, otkrića novih terapeutskih mehanizama praktično u zastoju. Ciljni molekuli preko kojih deluju antidepresivi koji su danas u upotrebi identifikovani su reverznim inženjeringom lekova otkrivenih empirijski, kliničkim zapažanjima. Otkad je jasno pokazano postojanje novonastalih neurona, adultna neurogeneza je postala izuzetno atraktivna potencijalna meta delovanja kandidata za antidepresivne lekove. Uvođenje inhibitora kortikotropin-oslobađajućeg hormona imalo je za cilj da se iskoristi činjenica da glukokortikoidni hormoni inhibiraju adultnu neurogenezu i time doprinose antisdepresivnom efektu. Iako su se ovi lekovi pokazali kao neefikasni u trećoj fazi kliničkih studija, naučene su sledeće važne lekcije za budućnost: (1) razlike u funkcionisanju mozga ljudi i životinja moraju biti pažljivo razmotrene, (2) da bi se zaključilo da animalni model ima depresivni fenotip, isti je potrebno ubedljivo demonstrirati, po mogućstvu korišćenjem većeg broja bihejvioralnih testova i (3) varijacije u simptomima između različitih podklasa depresije treba uzeti u obzir imajući u vidu heterogenost oboljenja.
\end{abstract}

Ključne reči: Depresija, Stres, Hipokampus, Adultna neurogeneza,

Glukokortikoidna signalizacija 